\title{
Whether, when and how chronic inflammation increases the risk of developing late-onset Alzheimer's disease
}

\author{
Piet Eikelenboom 1,2,3,*, Jeroen JM Hoozemans ${ }^{4}$, Rob Veerhui ${ }^{5}$, Eric van Exel ${ }^{3}$, Annemieke JM Rozemuller ${ }^{4}$ \\ and Willem A van Gool ${ }^{2}$
}

\begin{abstract}
Neuropathological studies have revealed the presence of a broad variety of inflammation-related proteins (complement factors, acute-phase proteins, pro-inflammatory cytokines) in Alzheimer's disease (AD) brains. These constituents of innate immunity are involved in several crucial pathogenic events of the underlying pathological cascade in $A D$, and recent studies have shown that innate immunity is involved in the etiology of late-onset AD. Genome-wide association studies have demonstrated gene loci that are linked to the complement system. Neuropathological and experimental studies indicate that fibrillar amyloid- $\beta(A \beta)$ can activate the innate immunityrelated CD14 and Toll-like receptor signaling pathways of glial cells for pro-inflammatory cytokine production. The production capacity of this pathway is under genetic control and offspring with a parental history of late-onset AD have a higher production capacity for pro-inflammatory cytokines. The activation of microglia by fibrillar A $\beta$ deposits in the early preclinical stages of $A D$ can make the brain susceptible later on for a second immune challenge leading to enhanced production of pro-inflammatory cytokines. An example of a second immune challenge could be systemic inflammation in patients with preclinical AD. Prospective epidemiological studies show that elevated serum levels of acute phase reactants can be considered as a risk factor for AD. Clinical studies suggest that peripheral inflammation increases the risk of dementia, especially in patients with preexistent cognitive impairment, and accelerates further deterioration in demented patients. The view that peripheral inflammation can increase the risk of dementia in older people provides scope for prevention.
\end{abstract}

\section{Introduction}

A role for inflammation in the pathogenesis of Alzheimer's disease $(\mathrm{AD})$ had been discussed even in the earliest days of $\mathrm{AD}$ research. A hundred years ago Oskar Fischer wrote that cerebral senile plaque formation could be considered as the result of an extracellular deposition of abnormal substance in the cortex that induces a local inflammatory reaction, followed by an aberrant regenerative response of the surrounding nerve fibers. However, he was unsuccessful in his attempts to show the morphological characteristics of an inflammatory response around plaques and to detect complement proteins by performing complement-binding studies. Seventy years later, with the advent of monoclonal antibodies for immunohistochemistry, complement factors and clustering of

*Correspondence: p.eikelenboom@ggzingeest.nl

Valeriuskliniek, Valeriusplein 9, 1075 BG Amsterdam, The Netherlands

Full list of author information is available at the end of the article activated microglia could be demonstrated within plaques [1]. After the discovery of amyloid- $\beta(A \beta)$ as the main constituent of senile plaques, the concept was formed that the $A \beta$ peptide itself can induce a local inflammatory response, which was supported by in vitro findings showing that fibrillar $\mathrm{A} \beta$ can bind complement factor $\mathrm{C} 1$ and activate the classical complement pathway without involvement of antibodies [2]. The inflammatory process in AD brains is not restricted to just a single step of the pathological process; inflammation-related proteins are involved in several crucial pathogenic events of the underlying pathological cascade, such as $\mathrm{A} \beta$ generation and clearance, gliosis and increased phosphorylation of tau with accelerated tangle formation [3,4]. It is important to keep in mind that inflammation itself has both beneficial effects, such as the phagocytosis of the toxic $A \beta$ fibrils, and detrimental effects on neighboring cells by prolonged elevation of pro-inflammatory mediators. Clinicopathological studies show that the presence of activated microglia and inflammation-related mediators 


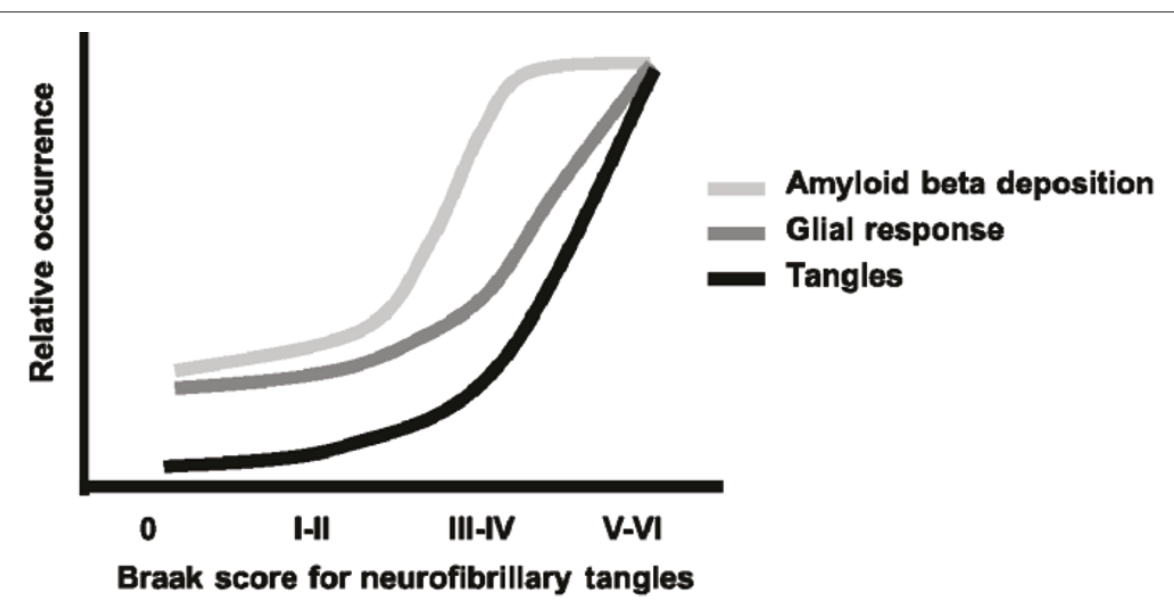

Figure 1. Pathological cascade in Alzheimer's disease brains. The occurrence of amyloid- $\beta$ deposits, glial response and tau-neurofibrillary pathology in the mid-temporal cortex compared to the neuropathological staging of Alzheimer's disease (modified after [5]).

in the cerebral neocortex of patients with a low Braak stage for $\mathrm{AD}$ pathology precedes extensive tau-related neurofibrillary pathology [5] (Figure 1). Clinical research using positron emission tomography with the peripheral benzodiazepine receptor ligand PK-11195 as a marker for activated microglia indicates that activation of microglia precedes cerebral atrophy in AD patients [6]. A positron emission tomography study using the Pittsburg compound $\mathrm{B}$ for visualization of fibrillar amyloid and the PK11195 ligand for microglia activation showed that amyloid deposition with microglia activation can be detected in vivo in around $50 \%$ of patients with mild cognitive impairment [7]. Thus, neuropathological and neuroradiological studies indicate that inflammatory changes in $\mathrm{AD}$ brains are a relatively early pathogenic event that precedes the process of neuropil destruction. The primary focus of the present paper is to review human studies for genetic, epidemiological and clinical evidence for whether, when and how inflammation could increase the risk of developing $\mathrm{AD}$.

\section{Genetic evidence}

In this section we evaluate the relationship between genetic risk factors for $\mathrm{AD}$ and two major components of amyloid plaques in $\mathrm{AD}$ brains, namely the presence of complement proteins and clusters of activated microglia, which are a source for the production of pro-inflammatory cytokines.

\section{$A \beta$-associated proteins}

Complement proteins were the first molecules detected in senile plaques in $\mathrm{AD}$ brains [8], two years before the identification of $A \beta$ as the core protein of the senile plaques in 1984. In the following years a growing list of other proteins, mostly acute phase proteins, were demonstrated to be associated with $A \beta$ deposits. These so-called $A \beta$-associated proteins include, next to the complement proteins, $\alpha 1$-antichymotrypsin (ACT), apolipoprotein E (ApoE), clusterin, intercellular adhesion molecule-1, $\alpha 2$-macroglobulin, serum amyloid $P$ component (SAP) and heparan sulfate proteoglycans [915]. These proteins play a role in the transport, fibrillogenesis and deposition of $A \beta$ and they are also important for the sequestration of neurotoxic $A \beta$ species in plaques [16]. The presence of certain $A \beta$-associated proteins within plaques depends on the plaque type (see below) $[17,18]$, and the accumulation of most depends on a certain degree of $A \beta$ fibrillization; for example, SAP is found especially in plaques with fibrillar $A \beta$ deposits but not in diffuse plaques [18]. In vitro studies also indicate that a certain degree of fibril formation is necessary for SAP to bind to $A \beta$, as SAP was found to bind to mature fibrils but not to protofibrils of A $\beta 1-42$ [19].

Neuropathological studies show that diffuse $A \beta$ deposits, characterized by the presence of non-fibrillar (noncongophilic) $A \beta$ and without neuritic changes or reactive glia, are the predominant plaque types in non-demented controls, and that the amount of fibrillar (congophilic) $A \beta$ deposits increases with progression of the disease [20]. In contrast to the classic plaques, characterized by highly fibrillar $A \beta$ deposits, the list of $A \beta$-associated proteins present in diffuse plaques is much shorter. Immunohistochemical studies have demonstrated that ApoE, clusterin, complement proteins and ACT are present in diffuse plaques [17]. Studies in transgenic mice expressing the causal $\mathrm{AD}$ mutations crossed with transgenic mice overexpressing or genetically depleted for amyloid-associated proteins such as complement factors, ApoE, clusterin and ACT have shown that these proteins have an important role in the dynamic balance 
between $A \beta$ deposition and removal [21-25]. Four recent large genome-wide association studies in late-onset $\mathrm{AD}$ have documented, in addition to the ApoE $\varepsilon 4$ allele genotype, nine novel loci as risk factors for developing $\mathrm{AD}$, including genes encoding proteins implicated in inflammatory processes (clusterin $(C L U$, chromosome 8 , rs11136000) and complement receptor-1 (CR1, chromosome 1 , rs6656401)) [26,27]. Clusterin is a multifunctional protein involved in both complement attack inhibition and cholesterol metabolism, and complement receptor-1 is the receptor for the cleavage products of complement proteins 3 and 4, which are present in plaques. All nine new genes map onto three pathways leading to late-onset $\mathrm{AD}$ : immune system function, cholesterol metabolism, and synaptic dysfunction [28]. Diffuse plaques, the initial pathological lesion in $\mathrm{AD}$, contain a limited number of proteins, which are now all linked with a genetic risk for $\mathrm{AD}$, with $\mathrm{ACT}$ as the exception. Abnormalities in the generation of $A \beta$ are considered as the causal factor for the familial forms of early-onset $\mathrm{AD}$, whereas polymorphisms of the genes encoding for ApoE, clusterin and complement proteins are the genetic risk factors for lateonset AD. Genome-wide association studies for lateonset $A D$ have not revealed genetic factors related to $A \beta$ generation but instead to the $A \beta$-associated proteins already present in the initial neuropathological lesion. Taken together, the data on the protein composition of diffuse plaques and the recent genetic findings strongly suggest an interaction between $A \beta$, cholesterol metabolism and complement activation in the initial steps of the pathological cascade in AD.

\section{Glia and pro-inflammatory cytokines}

Fibrillar $A \beta$ plaques are associated with clustering of activated microglia and astrocytes. These glial cells play an important role in innate immunity and express a family of receptors, the Toll-like receptors (TLRs), as a first line of defense responsible for recognizing specific pathogen-associated molecular patterns like fibrillar $A \beta$. TLRs and CD14, both innate immunity receptors, mediate activation of transcription factors such as NF- $\mathrm{kB}$ and subsequently the production of inflammatory cytokines [29]. Accumulating evidence indicates that CD14 and TLR4 are essential in the interaction of glial cells with $A \beta$ for the production of pro-inflammatory cytokines [30-32]. In vitro studies have shown that $\mathrm{A} \beta$ fibrils interact with the TLR2/4 accessory protein CD14 and both TLR2 and TLR4 mediate A $\beta$-induced production of TNF- $\alpha$ in human monocytes. Mouse microglia show in vitro increased ingestion of $A \beta$ after activation of TLR2, TLR4 or TLR9. Stimulation of the innate immune system via TLR9 is reported to be highly effective at reducing the parenchymal and vascular amyloid burden without apparent toxicity in a transgenic AD mouse model [33].
Both $A \beta$ and the oxidized low-density lipoprotein can trigger inflammatory signaling through a TLR4 and -6 heterodimer. This assemblage is regulated by signals from the scavenger receptor CD36 [34]. These data show that CD36-TLR4-TLR6 activation is a common molecular mechanism by which atherogenic lipids and $A \beta$ stimulate an inflammatory response in arteriosclerosis and $\mathrm{AD}$, respectively. Arteriosclerosis is a major risk factor for late-onset $\mathrm{AD}$ and the discussed findings suggest that both disorders share a common pathogenic mechanism rooted in the innate immune system. Introducing a functionally destructive mutant of TLR4 into a transgenic mouse model (APPswe/PS1) results in increased levels of $\mathrm{A} \beta$ deposits, as well as reduced microglia activity [35]. Microglia from CD14 null mice failed to affect A $\beta 1-42$ damaged neurons and neuronal survival was accompanied by a significant reduction in the production of IL-6, indicative of reduced microglial activation [36]. All these data suggest that activation of TLR4 and CD14 signaling is involved in both the detrimental production of pro-inflammatory cytokines as well as the beneficial removal of $A \beta$ in $A D$, illustrating the two-edged sword aspect of the neuroinflammatory response in AD brains [37]. Experimental animal studies indicate that microglia 'acivation' is not simply one phenotypic manifestation but includes heterogeneous, functional phenotypes that range from a pro-inflammatory, classic activation state to an alternative activation state involved in repair and extracellular matrix remodeling [38,39].

Lipopolysaccharide (LPS), a bacterial coat component, is widely used as a potent stimulator of the innate immune system and it is recognized by a receptor complex containing fully functional TLR4 and CD14. Chronic neuroinflammation induced by LPS in rats reproduced components of the neurobiology of $\mathrm{AD}$, such as increased activation of microglia and astrogliosis, increased tissue levels of IL-1 and TNF- $\alpha$, elevated expression of the amyloid precursor protein, and a working memory deficit [40]. Innate immunity responsiveness can be investigated by the incubation of whole blood samples with LPS, followed by the determination of levels of various inflammatory cytokines. Twin studies demonstrate that heritability for serum levels of circulating inflammatory mediators is modest (about 20\%). In contrast to circulating inflammatory mediators, however, cytokine production capacity is under strong genetic control. In the non-diseased population, estimates for the heritability of the production of the various cytokines ranges from 53 to $86 \%$ [41]. We have studied cytokine production capacity in ex vivo stimulated full blood samples from middle aged offspring with and without a parental history of late-onset $\mathrm{AD}$ [42]. We found that the production capacity of the pro-inflammatory cytokines IL-1 $\beta$, IL-6, TNF $\alpha$ and interferon- $\gamma$ was significantly 
higher in offspring with a parental history of AD upon stimulation of whole blood with LPS. Similar results were found for the IL-1 $\beta$ to IL-1 receptor antagonist (IL-1ra) ratio, which was calculated because IL-1ra is the natural antagonist of the pro-inflammatory cytokine IL-1 $\beta$. This higher ratio reflects a pro-inflammatory genotype. While the ApoE \&4 allele genotype was more frequent among the offspring with compared to those without a parental history of $\mathrm{AD}$, these findings were independent of ApoE4 genotype. In contrast to the stimulated whole blood samples, the evaluation of the unstimulated blood samples does not show significant differences between the offspring with versus without a parental history of lateonset $\mathrm{AD}$. The aim of this study was not to identify the genetic variability of a particular receptor or cytokine but to investigate the genetic contribution of the whole pathway that mediates the production of pro-inflammatory cytokines after activation by LPS of the innate immune receptors CD14 and TLRs by LPS. Similar to LPS, the A $\beta$-induced cytokine production capacity is also under genetic control, as shown by results from twin studies in which whole blood samples were ex vivo stimulated with $\mathrm{A} \beta$ [43].

In conclusion, neuropathological and experimental studies indicate that fibrillar $A \beta$ can activate the innate immunity-related CD14 and TLR signaling pathways for pro-inflammatory cytokine production. The production capacity of this pathway is under genetic control and offspring with a parental history of late-onset $\mathrm{AD}$ have a higher production capacity for pro-inflammatory cytokines.

\section{Epidemiological evidence}

Prospective case cohort studies have shown that high serum levels of the acute-phase proteins ACT, C-reactive protein and IL- 6 could predict cognitive decline or dementia [44-46]. Yaffe and colleagues [47] reported that elderly subjects with a metabolic syndrome and high serum level of IL-6 and C-reactive protein were more likely to experience cognitive decline in the next four years, compared with those with a metabolic syndrome and low levels of these inflammatory proteins. In another population study the metabolic syndrome was also negatively associated with cognition, especially in subjects with high levels of inflammation [48]. In the Framingham study a higher spontaneous production of IL-1 $\beta$ or TNF- $\alpha$ by peripheral blood mononuclear cells was associated with future risk of $\mathrm{AD}$ in older individuals [49]. The epidemiological findings from several case cohort studies indicate that non-demented subjects with increased serum levels of acute-phase reactants, indicating a low-grade peripheral systemic inflammation, are at risk for developing a sporadic late-onset form of AD.

The acute phase response is initiated and orchestrated by cytokines, most notably IL-1. AD brains are characterized by overexpression of IL-1 and there are strong arguments for an important role for IL-1 in amyloid plaque formation [50]. A $\beta$ deposition and neuronal injury may trigger a self-propagating cytokine cycle, which initiates a vicious feedback of continuing IL1 elevation when chronically induced. In this way further neuronal dysfunction and $A \beta$ plaque accumulation could be promoted. Taken together, the epidemiological studies suggest that elevated serum levels of acute phase reactants can be considered as a risk factor for $\mathrm{AD}$ and neuropathological data demonstrate the presence of acute phase reactants already in human brains with preclinical stages of AD pathology (low Braak score). Studies suggesting that immune blood markers can be used as a clinical test to identify those patients with mild cognitive impairment who progress to clinical $\mathrm{AD}$ are consistent with the view that peripheral immune and inflammatory mechanisms contribute to the pathogenesis of $\mathrm{AD}[51,52]$.

\section{Clinical evidence}

The question of whether systemic inflammation or peripheral chronic inflammation could contribute to AD pathology was a neglected research topic until recently. In particular, the dogmatic belief that the blood-brain barrier excludes cross-talk between both systems hampered studies in this field for a long time. This view has changed dramatically, however, as it became clear that morphological 'delegates' of the immune system, the microglial cells, are present in the brain and that the peripheral lymphoid organs are innervated. A further finding was that cytokines and neurotransmitters, as well as their receptors, are endogenous to both the brain and the immune system. These findings have led to the view that the immune system and brain share a common biochemical language and that their functions are intertwined [53]. Pro-inflammatory cytokines such as IL- $1 \beta$ and TNF- $\alpha$, which are generated in the periphery, communicate with the brain. Several mechanisms exist by which an initial, exclusively peripheral cytokine signal can be transmitted to the brain, including direct neural pathways (via primary autonomic afferents) that transport it across the blood-brain barrier, or entry via the cirvumventricular region, where the blood-brain barrier is non-existent or discontinuous [54].

Several clinical studies suggest that systemic inflammation can be involved in the pathogenesis of $\mathrm{AD}$. In a twin study it was found that AD cases with a history of severe systemic infection tended to have earlier onset than their corresponding twin [55]. A case-control case study reported a positive association between episodes of infection during the four years preceding the diagnosis and an increased likelihood of a diagnosis of AD in older individuals [56]. In a prospective cohort study of 
community-dwelling subjects with mild to severe AD it was found that acute episodes of systemic inflammation with increased serum levels of TNF- $\alpha$ were associated with a two-fold increase in the rate of cognitive decline over a 6-month period. High baseline levels of TNF- $\alpha$ were associated with a four-fold increase in the rate of cognitive decline while subjects who had low levels of TNF- $\alpha$ throughout the study showed no cognitive decline over the 6-month period [57]. Recent studies indicate that chronic periodontitis has been associated with AD. Periodontitis is a prevalent, persisting peripheral infection associated with Gram-negative, anaerobic bacteria that are capable of exhibiting localized and systemic infection in the host. Emerging evidence suggests that tooth loss and periodontal disease predict cognitive decline in community-dwelling older adults [58]. In addition, patients with $\mathrm{AD}$ had higher levels of plasma TNF- $\alpha$ and antibodies against periodontal bacteria compared with cognitively normal subjects [59]. Although several case-control and prospective studies indicate periodontitis as a risk factor for cognitive decline, it is important to be cautious to draw any conclusion about a causal relationship. Premorbid cognition is important both for oral health and a risk factor for dementia. Furthermore, factors other than inflammatory mediators could be responsible for the positive association, such as changes in life style and dietary factors, such as a poor nutritional status, especially in relationship to B vitamins.

Most interesting with regard to understanding the contribution of systemic inflammation to the pathogenesis of $\mathrm{AD}$ seems to be current research into the role of inflammation in delirium. Delirium is defined as an acute disturbance of consciousness with signs of attention, a typically fluctuating course and a change in cognition (that is, disorientation, disturbed memory). Delirium is the most prevalent neuropsychiatric syndrome that can be observed in the general hospital, especially in older patients with preexisting cognitive impairment. It is independently associated with increased mortality, institutionalization and dementia [60]. Many clinical conditions that are accompanied by systemic inflammatory reactions can induce delirium. A case-controlled neuropathological study has shown an association between severe systemic infection (sepsis) and microglia activation [61]. A recent postmortem study found that delirium is associated with higher immunoreactivity for microglial and astroglial activity and IL-6 compared with age-matched controls without delirium [62]. In healthy persons a severe systemic inflammation, such as sepsis, can lead to delirium, but in patients with preexisting brain pathology even just a mild urinary tract infection can cause it [63]. Experimental animal studies have shown that microglia respond differently to a stimulus if other stimuli precede, coexist or follow it. Microglia can become primed by an initial factor, which prepares them for an enhanced proinflammatory cytokine response, even if the subsequent challenges are only mild [64]. Significantly increased serum levels of IL-6 were found in acutely admitted older patients with delirium compared to those without delirium after adjusting for infection, age and cognitive decline [65]. This study indicates that acute phase reactants could contribute to the pathogenesis of delirium. A high incidence of delirium is seen in older patients undergoing surgery for hip fracture. Contrary to popular belief, there is little evidence that general anesthesia is associated with delirium after surgery [66]. The most important predisposing factor for delirium in these patients is preexisting cognitive decline or dementia. The precipitating factors could be related to the release of pro-inflammatory cytokines as a consequence of the fracture and tissue destruction resulting from surgery. In a time course study of cytokines during delirium in older patients admitted for surgery after hip fracture, significant differences in serum levels of IL- 6 were found between patients with and without delirium [67].

For a long time it has been a common observation in medicine that, when older patients become delirious while suffering from an acute urinary tract or other common infection, treatment of the infection may go well but the patients emerge with dementia, even when they had appeared cognitively intact or only mildly impaired prior to hospitalization. These patients often fail to recover to their initial level of functioning and some never resume independent life at home. Similar clinical observations have been made after postoperative delirium in elderly hip fracture patients free from preexisting dementia [68-70]. There is now increasing evidence that postoperative delirium after hip surgery is an important predictor of incident dementia in elderly patients living independently at home [70]. In a prospective study it was found that, after a follow-up of 2.5 years, the risk of dementia or mild cognitive impairment is almost doubled in elderly hip surgery patients with postoperative delirium compared with at-risk patients without delirium [68]. It has recently been reported that delirious episodes in a cohort of $\mathrm{AD}$ patients accelerate cognitive decline [71].

In conclusion, recent studies suggest that delirium and $\mathrm{AD}$ share a neuroinflammatory response as a common pathogenic mechanism that could explain the vulnerability of AD patients for further cognitive worsening after an episode of delirium associated with a systemic inflammatory reaction.

\section{Discussion}

The etiology of $\mathrm{AD}$ may be heterogeneous, but the underlying pathological cascade has distinct common themes. In the autosomal dominant form of familial $\mathrm{AD}$ 


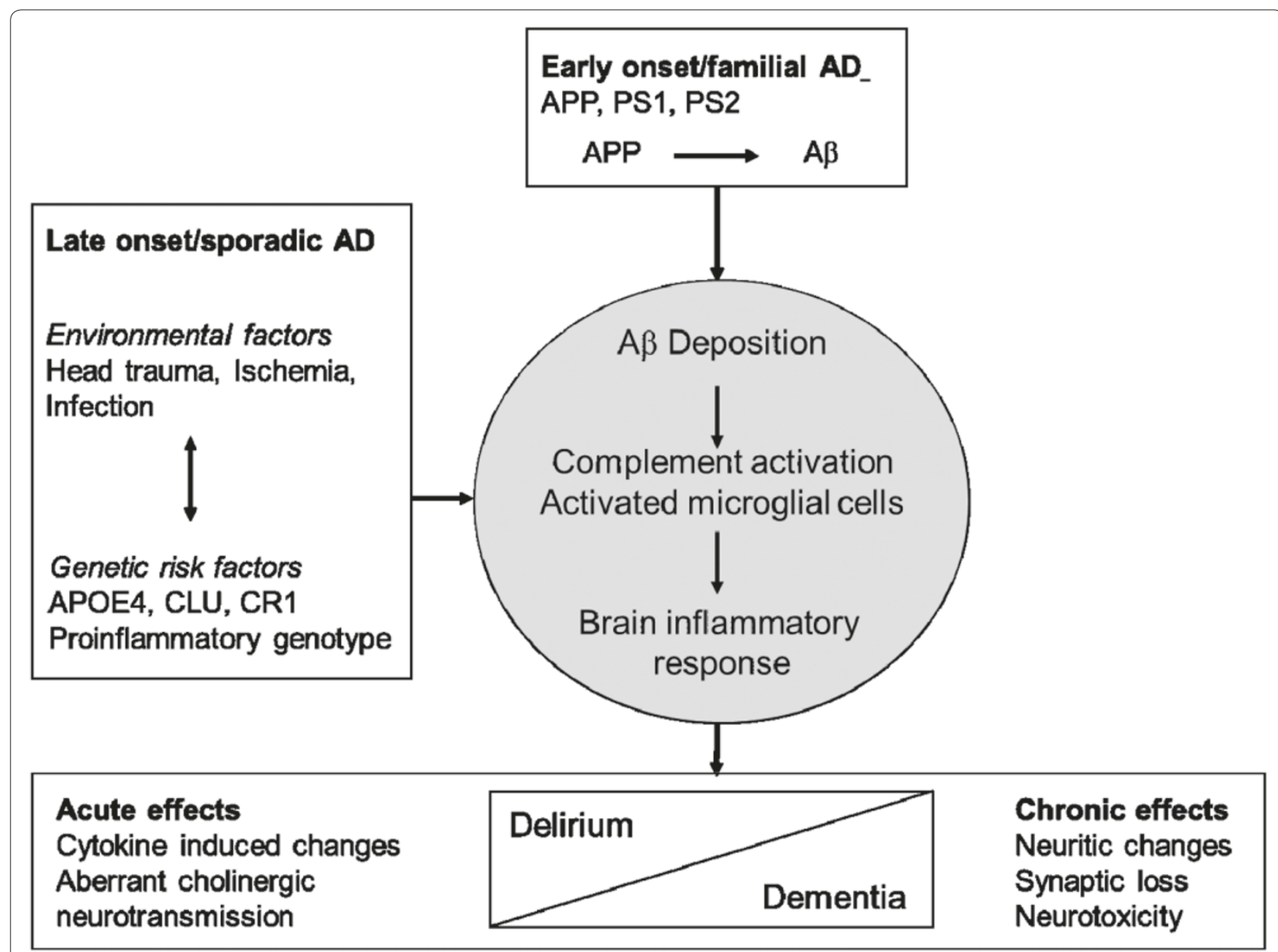

Figure 2. Relationship between inflammation and the etiology and clinical syndrome of Alzheimer's disease. Schematic diagram showing that interactions between innate immunity-related genetic risk factors and inflammation-inducing events (brain trauma, ischemia and infection) can contribute to the multifactorial etiology of the sporadic late-onset form of AD. The diagram illustrates also that delirium and AD share a neuroinflammatory response as a common pathogenic mechanism that could explain the vulnerability of AD patients to further cognitive worsening after an episode of delirium associated with a systemic inflammatory response. A $\beta$, amyloid- $\beta$ peptide; AD, Alzheimer's disease; APOE4, apolipoprotein E4; APP, amyloid precursor protein; CLU, clusterin; CR1, complement receptor-1; PS1, presenilin-1; PS2, presenilin-2.

the etiology is related to causal mutations leading to higher production of $\mathrm{A} \beta 1-42$. The subsequent deposition of fibrillar $\mathrm{A} \beta$ elicits a brain inflammatory response as a secondary event in the pathological process. In contrast to the monocausal etiology of this rare form of $\mathrm{AD}$, the etiology of the highly prevalent sporadic late-onset form is considered to be multifactorial. Genome-wide association studies of late-onset AD strongly suggest a role for lipoproteins and immune-associated proteins in its etiology and pathogenesis. In addition to the role of ApoE and clusterin in the process of $\mathrm{A} \beta$ deposition and drainage, these proteins can also attenuate the activity of NF- $\mathrm{kB}$ signaling and the production of pro-inflammatory cytokines [72,73]. The fibrillar A $\beta$-induced inflammatory response is a relatively early event in the pathological cascade and it is already present in the brain during stages of the disease that precede the stages characterized by tau-related neurofibrillary changes, which are most closely related to a clinical dementia syndrome (Figure 1).

Animal and neuropathological studies in humans show that systemic inflammation can induce an inflammatory response within the brain. This response can lead to acute cognitive disturbance and behavior changes (delirium) [74]. In healthy adults only a severe systemic inflammation can induce delirium, but in older people, especially those with mild cognitive impairment or dementia, even just a mild systemic inflammation can lead to it [75]. Inflammation-induced delirious episodes in adults with preexisting normal cognitive functions are frequently followed by a period of cognitive impairment that can last for months, although there is no evidence in these cases for a further progression of the cognitive symptoms to a clinical AD syndrome. However, inflammationinduced delirium in older patients with preexisting mild 
cognitive impairment can lead to further cognitive deterioration and dementia (Figure 2). These clinical findings suggest that systemic inflammation does not initiate the pathological AD cascade but can accelerate the underlying cascade.

What makes older patients with peripheral inflammation so vulnerable to dementia? Several mechanisms can play a role. First, neuropathological studies show inflammatory changes in early stages of AD pathology, such as fibrillar A $\beta$-induced microglia activation. Microglia cells are already 'primed' in preclinical stages of AD for increased production of pro-inflammatory cytokines later on by systemic inflammation as a second challenge. Second, neurotransmitters such as acetylcholine play an active role in controlling glia activation and can inhibit the production of proinflammatory cytokines [76]. AD brains are characterized by cholinergic deficits that can contribute to an uncontrolled neuroinflammatory response when the brain is challenged by peripheral inflammation. Third, arteriosclerosis and other vascular risk factors common in older people lead to blood-brain barrier dysfunction with brain endothelial cell activation resulting in the secretion of multiple neurotoxic and inflammatory factors. These factors could be responsible for the increased susceptibility of the brain to systemic inflammatory mediators $[77,78]$. This could also explain why the prevalence of delirium in demented patients in late-onset $\mathrm{AD}$ and vascular dementia is higher than in those with early onset AD [79].

The pathological, epidemiological and clinical findings reviewed in this paper suggest that several inflammationrelated events can contribute to the pathogenesis of $\mathrm{AD}$ and accelerate the rate of progression of the clinical course of AD. However, this view does not necessarily indicate that treatment with anti-inflammatory drugs will be effective in AD patients. As discussed earlier, inflammation itself has both beneficial and detrimental effects and every inflammation-based therapeutic strategy influences the delicate balance between both effects. Inhibition of complement activation or blocking of IL-1 $\beta$ have been considered as therapeutic options for treatment of $\mathrm{AD}$ patients. However, it appeared that complement $\mathrm{C} 3$ deficiency in transgenic AD mice led to accelerated amyloid plaque formation and overexpression of IL-1 $\beta$ to a reduction of amyloid pathology $[21,22,80]$. These findings indicate potential negative effects of anti-inflammatory drugs in $\mathrm{AD}$ patients if these drugs inhibit the primary function of the innate immune system: removal of the pathological agents (fibrillar $A \beta$ ) that induce the inflammatory response. Epidemiological and observational studies in humans have found evidence that the use of non-steroidal anti-inflammatory drugs (NSAIDs) is associated with a lower risk of developing AD. In contrast, randomized trials have reported no effect of
NSAIDs on clinical progression in patients with clinically established AD [81]. An explanation for these apparently divergent conclusions could be the fact that expression levels of cyclooxygenase- 1 and -2 , as the main targets of NSAIDs, are dependent on the stage of AD pathology [82].

\section{Further directions}

The view that peripheral inflammation can increase the risk of dementia in older people offers scope for prevention. In particular, clinical trials are warranted to investigate whether anti-inflammatory drugs can prevent further cognitive decline in patients with mild cognitive impairment during the periods that peripheral inflammation exerts increased inflammatory pressure on the brain. These studies could be performed using available drugs that inhibit microglia activation, such as minocycline, or that restore the cholinergic control of microglia activation by cholinomimetics [63]. Minocycline, a tetracycline derivative with anti-inflammatory properties, attenuates the production of pro-inflammatory cytokines by human microglia without affecting their beneficial activities, such as phagocytosis of $A \beta$ fibrils [83].

\section{Conclusion}

Genetic, pathological and epidemiological studies show that innate immunity is involved in the early stages of the pathological cascade of AD and can also contribute to the etiology of late-onset $\mathrm{AD}$. Clinical studies suggest that peripheral inflammation increases the risk of dementia, especially in patients with preexisting cognitive impairment, and accelerates further deterioration in demented patients.

\section{Abbreviations}

$A \beta$, amyloid- $\beta$; $A C T$, a1-antichymotrypsin; $A D$, Alzheimer's disease; ApoE, apolipoprotein $E_{;}$IL, interleukin; LPS, lipopolysaccharide; NF, nuclear factor; NSAID, non-steroidal anti-inflammatory drug; SAP, serum amyloid $P$ component; TLR, Toll-like receptor; TNF, tumor necrosis factor.

Competing interests

The authors declare that they have no competing interests.

\section{Authors' contributions}

PE, WAG, and JJM were involved in writing the manuscript. AJMR and RV contributed to the reviewed neuropathological findings and EvE to the epidemiological findings. All authors read and approved the final manuscript.

\section{Author details}

'Valeriuskliniek, Valeriusplein 9, 1075 BG Amsterdam, The Netherlands. ${ }^{2}$ Department of Neurology, Academic Medical Center, University of Amsterdam, Meibergdreef 9, 1105 AZ Amsterdam, The Netherlands. ${ }^{3}$ Department of Psychiatry, GGZIngeest/VU University Medical Center, A.J. Ernststraat 1187, 1081 HL Amsterdam, The Netherlands. ${ }^{4}$ Department of Pathology, VU University Medical Center, De Boelelaan 1117, 1081 HV Amsterdam, The Netherlands. ${ }^{5}$ Department of Clinical Chemistry and Alzheimer's Center, VU University Medical Center, De Boelelaan 1117, 1081 HV Amsterdam, The Netherlands.

\section{Acknowledgments}

Work discussed was supported by an EMGO fellowship of VUMC (EvE), Internationale Stichting Alzheimer Onderzoek (JJMH, ISAO\#08513) and ZonMW (WAvG, TOP\#40-00812-98-10017). 
Published: 4 June 2012

\section{References}

1. Eikelenboom P, Veerhuis R, Scheper W, Rozemuller AJM, van Gool WA Hoozemans JJM: The significance of neuroinflammation in understanding Alzheimer's disease. J Neural Transm 2006, 113:1685-1695.

2. Rogers J, Cooper NR, Webster S, Schulz J, McGeer PL, Styren SD, Civin WH, Brachova L, Bradt B, Lieberburg I: Complement activation by $\beta$-amyloid in Alzheimer's disease. Proc Natl Acad Sci U S A 1992, 89:10016-10020.

3. Heneka MT, O'Banion MK, Terwel D, Kummer MP: Neuroinflammatory processes in Alzheimer's disease. J Neural Transm 2010, 117:919-947.

4. Zilka, N, Kazmerova, Jadhav S, Neradi P, Madari A, Obetkova D, Bugos O, Novak M: Who fans the flames of Alzheimer's disease brains? Misfolded tau on the crossroad of neurodegenerative and inflammatory pathways. J Neuroinflammation 2012, 9:47

5. Hoozemans JJM, Veerhuis R, Rozemuller JM, Eikelenboom P. Neuroinflammation and regeneration in the early stages of Alzheimer's disease pathology. Int J Dev Neurosci 2006, 24:157-165

6. Cagnin A, Brooks DJ, Kennedy AM, Gunn RN, Myers R, Turkheimer FE, Jones T, Banati RB: In-vivo measurement of microglia in dementia. Lancet 2001, 358:461-467.

7. Okello A, Edison P, Archer HA, Turkheimer FE, Kennedy J, Bullock R, Walker Z, Kennedy A, Fox N, Rossor M, Brooks DJ: Microglial activation and amyloid deposition in mild cognitive impairment: a PET study. Neurology 2009, 72:56-62.

8. Eikelenboom P, Stam FC: Immunoglobulins and complement factors in senile plaques. An immunohistoperoxidase study. Acta Neuropathol 1982, 57:239-242

9. Abraham CR, Selkoe DJ, Potter H: Immunohistochemical identification of the serine protease inhibitor a1-antichymotrypsin in the brain amyloid deposits of Alzheimer's disease. Cell 1989, 52:487-501.

10. Namba Y, Tomonaga M, Kawasaki H, Otomo E, Ikeda K: Apoliporotein E immunoreactivity in cerebral amyloid deposits and neurofibrillary tangles in alzheimer's diseaseand kuru plaque amyloid in Creutzfeldt-Jakob disease. Brain Res 1991, 541:163-166.

11. Choi-Miura NH, Ihara Y, Fukuchi K, Takeda M, Nakano Y, Tobe T, Tomita M: SP-40,40 is a constituent of Alzheimer's amyloid. Acta Neuropathol 1992, 83:260-264.

12. Rozemuller JM, Eikelenboom P, Pals ST, Stam FC: Microglial cells around plaques in Alzheimer's disease express leucocyte adhesion molecules of the LFA-1 family. Neurosci Lett 1989, 101:288-292

13. Bauer J, Strauss S, Schreiter-Gasser U, Ganter U, Schlegel P, Witt I, Yolk B, Berger M: Interleukin-6 and a2-macroglobulin indicate an acute-phase state in Alzheimer's disease. FEBS Lett 1991, 285:111-114

14. Coria F, Castano E, Prelli F, Larrondo-Lillo M, van Duinen S, Shelanski ML, Frangione B: Isolation and characterization of amyloid P component from Alzheimer's disease and other types of cerebral amyloidosis. Lab Invest 1988, 58:454-458.

15. Snow AD, Mar H, Nochlin D, Kimata K, Kato M, Suzuki S, Hassell J, Wight TN: The presence of heparin sulfate proteoglycans in the neuritic plaques and congophilic angiopathy in Alzheimer's disease. Am J Pathol 1988, 133:456-463.

16. Veerhuis R, Boshuizen RS, Familian A: Amyloid associated proteins in Alzheimer's and prion disease. Curr Drug Targets CNS Neurol Disord 2005, 4:235-248.

17. Zhan SS, Veerhuis R, Kamphorst W, Eikelenboom P: Distrubution of $\beta$-amyloid associated proteins in plaques in Alzheimer's disease and non-demented elderly. Neurodegeneration 1994, 4:291-297

18. Veerhuis R, van Breemen, MJ, Hoozemans JJM, Morbin M, Ouladhadj J, Tagliavini F, Eikelenboom P: Amyloid- $\beta$ plaque-associated proteins $\mathrm{C} 1 \mathrm{q}$ and SAP enhance the A $\beta 1-42$ peptide-induced cytokine production in adult human microglia in vitro. Acta Neuropathol 2003, 105:135-144.

19. Holm Nielsen E, Nybo M, Junker K, Toftedal Hansen P, Rasmussen IM, Svehag SE: Loccalization of human serum amyloid $P$ component and heparin sulphate proteoglycan in vitro-formed A $\beta$ fibrils. Scand J Immunol 2000, 52:110-112

20. Morris JC, Storandt M, MCKeel DW Jr, Rubin EH, Price JL, Grant EA, Berg L: Cerebral amyloid deposition and diffuse plaques in 'normal' aging. Evidence for presymptomatic and very mild Alzheimer's disease. Neurology 1996, 46:707-719.

21. Wyss-Coray T, Yan F, Lin AH, Lambris JD, Alexander JJ, Quigg RJ, Masliah E:
Prominent neurodegeneration and increased plaque formation in complement inhibited Alzheimer's mice. Proc Natl Acad Sci U S A 2002, 99:10837-10842

22. Maier M, Peng Y, Jiang L, Seabrook TJ, Carroll MC, Lemere CA: Complement C3 deficiency leads to accelerated amyloid- $\beta$ plaque deposition and neurodegeneration and modulation of the microglia/macrophage phenotype in amyloid precursor protein transgenic mice. J Neurosci 2008 28:6333-6341.

23. Bales KR, Verina T, Dodel RC, Du YS, Altstiel L, Bender M, Hyslop P, Johnstone EM, Little SP, Cummins DJ, Ricardo P, Ghetti B, Paul SM: Lack of apoliprotein E dramatically reduces amyloid $\beta$-peptide deposition. Nat Genet 1997 17:263-264.

24. Nilsson LNG, Bales KR, DiCarlo G, Gordon MN, Paul SM, Potter H: a1Antichymotrypsin promotes $\beta$-sheet amyloid plaque formation in a transgenic mouse model of Alzheimer's disease. J Neurochem 2001, 21:1444-1451.

25. DeMattos RB, O'dell MA, Parsadanian M, Taylor JW, Harmony JA, Bales KR, Paul $\mathrm{SM}$, Aronow BJ, Holtzman DM: Clusterin promotes amyloid plaque formation and it is critical for neuritic toxicity in a mouse model of Alzheimer's disease. Proc Natl Acad Sci U S A 2002, 99:10843-10848.

26. Harold D, Abraham R, Hollingworth P, Sims R, Gerrish A, Hamshere ML, Pahwa JS, Moskvina V, Dowzell K, Williams A, Jones N, Thomas C, Stretton A, Morgan AR, Lovestone S, Powell J, Proitsi P, Lupton MK, Brayne C, Rubinsztein DC, Gill M, Lawlor B, Lynch A, Morgan K, Brown KS, Passmore PA, Craig D, McGuinness B, Todd S, Holmes C, et al.: Genome-wide association study identifies variants at CLU and PICALM associated with Alzheimer's disease. Nat Genet 2009, 41:1088-1093.

27. Lambert JC, Heath S, Even G, Campion D, Sleegers K, Hiltunen M, Combarros O, Zelenika D, Bullido MJ, Tavernier B, Letenneur L, Bettens K, Berr C, Pasquier F, Fievet N, Barberger-Gateau P, Engelborghs S, De Deyn P, Mateo I, Franck A, Helisalmi S, Porcellini E, Hanon O, de Pancorbo MM, Lendon C, Dufouil C, Jaillard C, Leveillard T, Alvarez V, Bosco P, et al:: Genome-wide association study identifies variants at CLU and CR1 associated with Alzheimer's disease. Nat Genet 2009, 41:1094-1099.

28. Morgan K: The three new pathways leading to Alzheimer's disease. Neuropathol Appl Neurobiol 2011, 37:353-357.

29. Takeuchi O, Akira S: Pattern recognition receptors and inflammation. Cell 2010, 149:805-820.

30. Fassbender K, Walter S, Kuhl S, Landmann R, Ishii K, Bertsch T, Stalder AK, Muehlhauser F, Liu Y, Ulmer AJ, Rivest S, Lentschat A, Guulbins E, Jucker M, Staufenbiel M, Brechtel K, Walter J, Multhaup G, Penke BM Adachi Y, Hartmann T, Beyreuther K: The LPS receptor (CD14) links innate immunity with Alzheimer's disease. Faseb J 2004, 18:203-2005

31. Tahara K, Kim HD, Jin JJ, Maxwell JA, Li L, Fukuchi K: Role of toll-like receptor signalling in $A \beta$ uptake and clearance. Brain 2006, 129:3006-3019.

32. Reed-Geaghan EG, Savage JC, Hise AG, Landreth GE: CD14 and toll-like receptors 2 and are required for fibrillar $A \beta$-stimulated microglial activation. J Neurosci 2009, 29:11982-11992.

33. Scholtzova H, Kascsak RJ, Bates KA, Boutajangout A, Kerr DJ, Meeker HC, Mehta PD, Spinner DS, Wisniewski T: Induction of toll-like receptor 9 signalling as a ethod for ameliorating Alzheimer's disease-related pathology. J Neurosci 2009, 29:1846-1854.

34. Stewart CR, Stuart LM, Wikinson K, van Gils JM, Deng J, Halle A, Rayner KJ, Boyer L, Zhong R, Frazier WA, Lacy-Hulber A, El Khoury J, Golenbock DT, Moore KJ: CD13 ligands promote sterile inflammation through assembly of a Toll-like receptor 4 and 6 dimer. Nat Immunol 2010, 11:155-161.

35. Walter S, LetiembreM, Liu Y, Heine H, Penke B, Hao W, Bode B, Manietta N, Walter J, Schulz-Schaffer W, Kassbender K: Role of Toll-like receptor 4 in neuroinflammation in Alzheimer's disease. Cell Physiol Biochem 2007 20:947-956.

36. Bate C, Veerhuis R, Eikelenboom P, Williams A: Microglia kill amyloid- $\beta 1-42$ damaged neurons by a CD14-dependent process. NeuroReport 2004, 15:1427-1430

37. Wyss-Coray T, Mucke L: Inflammation in neurodegenerative disease a double edge sword. Neuron 2002, 35:419-432.

38. Town T, Nicolic V, Tan J: The microglial "activation" continuum: from innate to adaptive responses. J Neuroinflammation 2005, 2:24.

39. Colton CA, Mott RT, Sharpe H, Xu, Q, Van Nostrand WE, Vitek MP: Expression profiles for macrophage alternatives activation genes in $A D$ and in mouse models of AD. J Neuroinflammation 2006, 3:27.

40. Hauss-Wegrzyniak B, Dobrzanski P, Stoehr JD, Wenk GL: Chronic 
neuroinflammation in rats reproduces components of the neurobiology of Alzheimer's disease. Brain Res 1998, 780: 294-303.

41. de Craen AJ, Posthuma D, Remarque EJ, van den Biggelaar AH, Westendorp RGJ: Heritability estimates of innate immunity: an extended twin study. Genes Immun 2005, 6:167-170.

42. van Exel E, Eikelenboom P, Comijs H, Frolich M, Smit JH., Stek ML, Scheltens P, Eefsting JE, Westendorp RGJ: Vascular factors and markers of inflammation in offspring with a parental history of late-onset Alzheimer disease. Arch Gen Psychiat 2009, 66:1263-1270.

43. Posthuma D, Meulenbelt I, de Craen AJM, de Geus EJC, Slagboom PE, Boomsma DI, Westendorp RGJ: Human cytokine response ex vivo amyloid- $\beta$ is mediated by genetic factors. Twin Res Hum Genet 2005, 8:132-137.

44. Schmidt R, Schmidt H, Curb JD, Masaki K, White LR, Launer LJ: Early inflammation and dementia: a 25-year follow-up of the Honolulu-Asia aging study. Ann Neurol 2002, 52:168-174.

45. Engelhart MJ, Geerlings MI, Meijer J, Kilaan A, Ruitenberg A, van Swieten JC, Stijnen T, Hofman A, Witteman JC, Breteler MMB: Inflammatory proteins in plasma and the risk of dementia: the Rotterdam study. Arch Neurol 2004, 61:668-672

46. Dik MG, Jonker C, Hack CE, Smit JH, Comijs HC, Eikelenboom P: Serum inflammatory proteins and cognitive decline in older patients. Neurology 2005, 64:1371-1377.

47. Yaffe K, Kanaya A, Lindquist K, Simonsick EM, Harris T, Shorr RI, Tylavsky FA, Newman AB: The meatboloc syndrome, inflammation, and the risk of cognitive decline. JAMA 2004, 292:2237-2242.

48. Dik MG, Jonker C, Comijs HC, Deeg DJ, Kok A, Yaffe K, Pennix BW: Contribution of metabolic syndrome components to cognition in older individuals. Diabetes Care 2007, 30:2655-2660.

49. Tan ZS, Beiser AS, Vasan RS, Roubenoff R, Dinarello CA, Harris TB, Benjamin EJ, Au R, Kiel DP, Wolf PA, Seshadri S: Inflammatory markers and the risk of Alzheimer's disease: The Framingham study. Neurology 2007, 68:1902-1908.

50. Griffin WST, Sheng JG, Royston MC, Mackenzie JE, Graham DI, Roberts GW, Mrak RE: Glial-neuronal interactions in Alzheimer's disease; the potential role of a 'cytokine cycle'in disease progression. Brain Pathol 1998, 8:65-72.

51. Ray S, Britschgi M, Herbert C, Takeda-Uchimera Y, Boxer A, Blennow K, Friedman LF, Galasko D, Jutel M, Kaydas A, Kaye JA, Lezsek L, Miller BL, Minthon L, Quinn JF, Rabinovic GD, Robinson WHJ, Sabbagh MW, So YT, Sparks L, Tabaton M, Tinklenberg J, Yeavage JA, Tibshrana R, Wyss-Coray T: Classification and prediction of clinical Alzheimer's diagnosis based on plasma signaling proteins. Nat Med 2007, 11:1359-1362.

52. Avagyan H, Goldenson B, Tse E, Masoumi A, Porter V, Wiedau-Pazos M, Sayre J, Ong R, Mahanian M, Koo P, Bae S, Miodrag M, Liu PT, Rosenthal MJ, Fiala M: Immune blood biomarkers of Alzheimer disease patients. J Neuroimmunol 2009, 210:67-72.

53. Blalock JE: The syntaxis of immune-neuroendocrine communication. Immunol Today 1994, 15:504-511.

54. Dantzer R, O'Connor JC, Freund GG, Johnson RW, Kelly KW: From inflammation to sickness and depression: when the immune system subjugates the brain. Nat Rev Neurosci 2008, 9:46-56

55. Nee LE, Lippa CF: Alzheimer's disease in 22 twins pairs-13 years follow-up. Hormonal, infectious and traumatic factors. Dement Geriatr Cogn Disord 1999, 10:148-151.

56. Dunn N, Mullee M, Perry VH, Holmes C: Association between dementia and infectious disease: evidence from a case-control study. Alzheimer Dis Assoc Disord 2005, 19:91-94.

57. Holmes C, Cunningham C, Zotova E, Woolford J, Dean C, Kerr S, Culliford D, Perry VH: Systemic inflammation and disease progression in Alzheimer's disease. Neurology 2009, 73:768-774.

58. Kamer AR, Morse DE, Holm-Pedersen P, Mortensen EL, Avlund K: Periodontol inflammation in relation to cognitive function in an older Danish population. J Alzheimers Dis 2012, 28:613-624.

59. Kamer AR, Craig RG, Pirraglia E, Dasanayaka AP, Norman RG, Boylan RJ, Nehorayoff A, Glodzik L, Brys M, de Leon MJ: TNF- $a$ and antibodies to periodontal bacteria discriminate between Alzheimer's disease patients and normal subjects. J Neuroimmunol 2009, 216:92-97.

60. Witlox J, Eurelings LS, de Jonghe JFM, Kalisvaart KJ, Eikelenboom P, van Gool WA: Delirium in the elderly and the risk of postdischarge mortality, institutionalization, and dementia: a meta-analysis. JAMA 2010, 304:443-451.

61. Lemstra AW, Groen in't Woud JC, Hoozemans JJM, van Haastert ES, Rozemuller AJM, Eikelenboom P, van Gool WA: Microglia activation in sepsis: a case-control study. J Neuroinflammation 2007, 4:4.
62. van Munster BC, Aronica E, Zwinderman AH, Eikelenboom P, Cunningham C, de Rooij SE: Neuroinflammation in delirium: a postmortem case-control study. Rejuvenation Res 2011, 14:515-622.

63. van Gool WA, van de Beek D, Eikelenboom P: Systemic infection; when cytokines and acetylcholine collide. Lancet 2010, 375:773-775.

64. Perry VH, Cunningham C, Holmes C: Systemic infections and inflammation affect chronic neurodegeneration. Nat Rev Immunol 2007, 7:161-167.

65. de Rooij SE, van Munster BC, Korevaar JC, Levi M: Cytokines and acute phase response in delirium. J Psychosom Res 2007, 62:521-525.

66. Slor CJ, de Jonghe JFM, Groot E, van der Ploeg T, van Gool WA, Eikelenboom P, Snoeck M, Schmand B, Kalisvaart KJ: Anesthesia and postoperative delirium in older adults undergoing hip surgery. J Am Geriatr Soc 2011, 59:1313-1319.

67. van Munster BC, Korevaar JC, Zwinderman AH, Levi M, Wiersinga WJ, de Rooij SE: Time-course of cytokines during delirium in elderly with hip fractures. J Am Geriatr Soc 2008, 56:1704-1709.

68. Kat MG, Vreeswijk R, de Jonghe JFM, van der Ploeg T, van Gool WA, Eikelenboom P, Kalisvaart KJ: Long-term cognitive outcome of delirium in elderly hip surgery patients. A prospective matched controlled study over two and a half year. Dem Geriatr Cogn Disord 2008, 26:1-8.

69. Bickel H, Gradinger R, Kochs E, Förstl H: High risk of cognitive and functional decline after postoperative delirium; a three years prospective study. Dem Geriatr Cogn Disord 2008, 26:26-31.

70. Krogseth M, Wyller TB, Engedal K, Juliebo V: Delirium is an important predictor of incident dementia among elderly hip fracture patient. Dement Geriatr Cogn Disord 2011, 31:63-70.

71. Fong TG, Jones RN, Shi P, Maracantonio ER, Yap L, Rudolph JL, Yang FM, Kiely DK, Inouye SK: Delirium accelerates cognitive decline in Alzheimer disease. Neurology 2009, 72:1570-1575.

72. Zhu Y, Kodvawala A, Hui DY: Apolipoprotein E inhibits Toll-like recepto (TLR)-3 and TLR-4 mediated macrophage activation through distinct mechanisms. Biochem J 2010, 428:47-54.

73. Santilli G, Aronow BJ, Sala A: Essential requirement of apolipoprotein J (clusterin) signaling for IKB expression and regulation of NF-KB activity. J Biol Chem 2003, 278:38214-38219.

74. Chen J, Buchanan JB, Sparkman NL, Godbout JP, Freund GG, Johnson RW: Neuroinflammation and disruption in working memory in aged mice after stimulation of the peripheral innate immune system. Brain Behav Immun 2008, 22:301-311.

75. Girard TD, Jackson JC, Pandharipande PP, Pun BT, Thompson JL, Shintani AK, Gordon SM, Canonico AE, Dittus RS, Bernard GR, Ely EW: Delirium as predictor of long-term cognitive impairment in survivors of critical illness. Crit Care Med 2010, 38:1513-1520.

76. Carnevale D, de Simone R, Minghetti L: Microglia-neuron interaction in inflammatory and degenerative diseases: role of cholinergic and noradrernegic systems. CNS Neurol Disord Drug Targets 2007, 6:388-397.

77. Zlokovic BZ: Neurovascular pathways to neurodegeneration in Alzheimer's disease and other disorders. Nat Rev Neurosci 2011, 12:723-738.

78. Grammas P: Neurovascular dysfunction, inflammation and endothelial activation. Implications for the pathogenesis of Alzheimer's disease. J Neuroinflammation 2011, 8:26.

79. Robertsson B, Blennow K, Gottfries CG, Wallin A: Delirium in dementia. Int J Geriatr Psychiatry 1998, 13:49-56

80. Shaftel SS, Kyrkanides S, OlschowskaJA, Miller JN, Jonson RE, O'Banion MK: Sustained hippocampal II- $1 \beta$ overexpression mediates chronic neuroinfklammation and ameliorates Alzheimer plaque pathology. J Clin Invest 2007, 117:1595-1604

81. Szekely CA, Zandi PP: Non-steroidal anti-inflammatory drugs and Alzheimer's disease: the epidemiological evidence. CNS Neurol Disord Drug Targets 2010, 9:132-139.

82. Hoozemans JJM, Rozemuller JM, van Haastert ES, Veerhuis R, Eikelenboom P: Cyclooxygenase- 1 and -2 in the different stages of Alzheimer's disease pathology. Curr Pharm Des 2008, 14:1419-1427.

83. Familian A, Eikelenboom P, Veerhuis R: Minocycline does not affect amyloid$\beta$ phagocytosis. Neurosci Lett 2007, 416:87-91.

\section{doi:10.1186/alzrt118}

Cite this article as: Eikelenboom P, et al.: Whether, when and how chronic inflammation increases the risk of developing late-onset Alzheimer's disease. Alzheimer's Research \& Therapy 2012, 4:15. 